\title{
El zumbanacuy: enfrentamiento ritual entre negros mayores y negritos bailadores en los Andes centrales de Perú
}

Este escrito tiene por objeto reflexionar acerca de una batalla ritual agrícola llamada zumbanacuy protagonizada por la población de Huayucachi, la cual se divide en dos segmentos siguiendo el espacio andino del hatun y urin; han sumado aspectos de su historia local y regional, así como una visión de lo afro que será interpretado bajo el enfoque afroindolatinoamericano. El ritual confronta a dos grupos sociales, los ricos o gamonales y la gente del pueblo, los pobres, los runas o chinchilpos. Se intenta mostrar las diferentes confluencias de lo afroindolatinoamericano en dicho acontecimiento a través de los testimonios de los protagonistas de dicha batalla con fines agrícolas.

Palabras Clave: afroindolatinoamericano, zumbanacuy, negros mayores, negritos bailadores, Huayucachi.

\section{The Zumbanacuy: a ritual confrontation between 'negros mayores' and 'negritos bailadores' in Peru's central Andes}

\begin{abstract}
This article aims to reflect on an agricultural ritual battle called zumbanacuy starring the population of Huayucachi, which is divided into two segments following the Andean space of hatun and hurin. They have added aspects of their local and regional history, as well as a vision of Afro that will be interpreted under the Afro-Indian-Latin-American approach. The ritual confronts two social groups: the rich or gamonales and the people of the town, the poor, the runas or chinchilpos. It tries to show the different confluences of the Afroindolatinoamericano in this event through the testimonies of the protagonists of this battle for agricultural purposes.
\end{abstract}

KEYwORDs: afroindolatinoamericano; Zumbanacuy; negros mayores; negritos dance; Huayucachi. 
E n las siguientes líneas reflexionaré sobre el zumbanacuy de negros mayores y negritos bailadores de Huayucachi, en el distrito de Huancayo, región Junín. En esta zona se pueden identificar algunas danzas representativas relacionadas con la agricultura y la ganadería. Por ejemplo, el caso de la festividad y danza llamada Santiago, dedicada al Tayta Wamani o Santiago Apóstol, se lleva a cabo en los meses de julio y agosto en el valle del Mantaro, vinculadas a la protección de los ganados y de las familias de la zona. ${ }^{1}$ Existen otras plenamente de carácter agrícola como el huaylarsh, llevada a cabo en la época del carnaval.

En el Valle del Mantaro, en el centro de la zona andina de Perú, se ubica una gama diversa de expresiones religiosas y rituales acompañadas por variadas comparsas dancísticas, las cuales, en palabras de los propios pobladores de la zona, es tan amplia que cada día se puede asistir a una festividad patronal durante el año.

La zona del río Mantaro, anteriormente denominada Hatun Mayo, comprende los antiguos territorios de xauxas y huancas, ${ }^{2}$ lejos está este escrito de profundizar en la historia de la región. Interesa particularmente seńalarlo como parte del Chinchaysuyo, una de las cuatriparticiones realizadas por los incas en su dominio político, social y cultural. Los huancas fueron aliados de los españoles en el siglo XVI. Por ello diferentes autores (Espinoza 1971; Arguedas 1957a) los identifican como un grupo que obtuvo privilegios de los conquistadores: el escaso establecimiento de haciendas; la poca población española en su territorio, no obstante que Jauja fue la primera capital del Perú, posteriormente trasladada a Lima, lugar al que se dirigieron los invasores europeos; la minería en las regiones aledańas a la región huanca, como La Oroya o Huancavelica; y la cercanía con la zona selvática, permitieron el crecimiento económico y político de la región de Junín, cuyo departamento central es Huancayo.

Huancayo es un centro importante de actividad económica actual, al mismo tiempo también tiene

1 Puede verse Arroyo (1987, 2008), García Miranda y Tacuri Aragón (2006).

2 No obstante que algunos autores los identifican como una misma presencia étnica antes de la llegada de los espańoles, otros coinciden en diferenciar étnicamente a dichos segmentos, pero en la actualidad comprenden un territorio con expresiones culturales similares. Puede consultarse García Torres (2018) y Hurtado Ames (2013). presencia un conjunto dancístico tan amplio que permite detectar danzas agrícolas, como el huaylash, los segadores; ganaderas como el toril, la llamichada o Santiago, antes referido; algunas plenamente reconocidas de origen anterior a los españoles, como las collas; otras típicamente de influencia española-religiosa como la calachaquis, la Jija; las históricas que reflejan parte del conflicto armado del siglo XIX con Chile, tal es caso de el chiple, o bien de tipo histórico del Perú, como los avelinos; de sátira, la chonguinada y la tunantada; o bien de tipo plenamente ritual como la huaconada. (Fiesta en los andes. Ritos, música y danza del Perú 2008; «La negrería en el Perú» 2010; Orellana Valeriano 1990, 2007; Parra Herrera 2009; García Miranda y Tacuri 2006; Vilcapoma 2008; Rojas y Palacios 1988; Robles Mendoza 2012; Pampa Chaccalla 1991; Enríquez Bergna 2011; Romero 2004). A su vez, también se distingue por la fuerte presencia de danzas referidas a lo afro, en sus diversas acepciones, de negrería, de negros o morenadas. (Celestino 2004; Sánchez 2010; Vásquez, Chalena 2010; Millones 2010; Alarco 2010; Orellana 2007; Schmidt 2007; Rocca Torres 2010, entre otros).

En este trabajo me referiré a una de las expresiones de esas danzas llamadas de negros o negrería para colocar el acento en una revuelta simbólica a partir de una danza agraria y la convergencia étnica y cultural de distintos segmentos de la población, el zumbanacuy en la confluencia cultural andina, la africana y la española por medio de lo afroindolatinoamericano.

La propuesta de análisis se enmarca en una vertiente que busca enlazar las relaciones o contactos entre población traída de África y la población originaria del continente después de la llegada de los españoles. Dicha propuesta es denominada Afroaindoamérica y lo afroindolatinoamericano (Serna 2014; Serna y Solís 2012; Serna 2010). Consiste en concebir las relaciones entre lo africano, lo indígena-originario, lo mestizo y lo blanco en una misma condición, sin menoscabar a ninguno de los involucrados, y, por el contrario, buscar las intersecciones de las relaciones sociales entre dichos grupos y superar así una condición de invisibilidad de lo afro en los Andes. Así, Afroamérica integra distintas regiones y comunidades de nuestro continente, surgida del traslado de población africana a regiones originarias a partir del siglo XVI, que presentó procesos complejos de relaciones interétnicas. Las poblaciones de origen africano 
y andina compartieron territorios y espacios simbólicos comunes, intercambiaron genes y elementos culturales. Esas relaciones, sin embargo, estuvieron caracterizadas por la dominación, sometimiento y esclavitud de dichos grupos humanos; fueron oprimidos por la hegemonía español-occidental-europea y en particular por el grupo gamonal, terratenientes o curacas ricos de la zona andina. ${ }^{3}$ La población afrodescendiente enfrentó, entre otros, la esclavitud en su territorio, su traslado a América significó una colonización más, y su inserción en un territorio bajo el dominio español fue otra.

En este sentido, es indispensable hacer un breve recuento sobre la forma en que se ha interpretado el contacto de la población africana y andina, para después colocar el acento en la danza actual de chinchilpos y gamonales a partir de la perspectiva afroindolatinoamericana que pone el énfasis en los contactos culturales entre esos grupos y, por supuesto, la influencia de los españoles.

Este trabajo deriva de una etnografía recabada durante la celebración en honor al Tayta Niño de Huayucachi, el último domingo de enero y el primer lunes de febrero del año 2014, periodo que comprendió un registro detallado de dicha actividad y se enmarcó como parte de un capítulo de la tesis doctoral sobre el territorio en sus dimensiones políticas, sociales y culturales, no abordadas de manera amplia en este trabajo.

\section{Zumbanacuy}

Pierre Duviols (1997) refiere dos relatos traducidos por Betanzos en los cuales se menciona una batalla «épica que se cantaba y de una batalla ritual que se desarrollaba en el Cuzco incaico" (Duviols: 1997, 281). Describe dos momentos en la historia del Cuzco, la de Pachacuti y Mayta Cápac. Dos relatos históricamente distintos en el que subyacen el mito y el rito, en una perspectiva de la simbología.

3 Las referencias a lo hegemónico es entendido en los términos de Gramsci (1975: 17-18) como un aspecto superestructural del grupo dominante, en este caso los esclavistas europeos y los gamonales, representantes del sistema colonial dominante; en contra parte con lo subalterno, es decir los grupos dominados, esclavos africanos llegados a la zona andina así como la población campesina, los runas o chinchilpos, como serán denominados más adelante.
Los elementos retomados de las crónicas coloniales, en versión de Duviols, remarcan aspectos míticos y rituales de «sendas mitades [que] representaban y conmemoraban ritualmente las hazañas guerreras de sus respectivos príncipes» (Pachacuti y Mayta Cápac), refleja la división hanan y urin (Duviols: 1997, 287), «una relación de oposición y complementariedad entre lo alto y lo bajo" por medio de una batalla ritual.

Una afirmación relevante sobre la forma en que se reorganizaron política, social e identitariamente los ayllus después del triunfo inca sobre los chancas, es un probable elemento de las batallas rituales, tal como lo afirma Duviols: «Según este primer esquema o modelo que sugieren los documentos, es presumible que los alcauizas debían proclamarse 'naturales', lo del ayllo real 'advenedizos', y cada uno de estos ayllus debía armar periódicamente un grupo de campeones que peleasen unos contra otros para recordar y confirmar dialécticamente su idiosincrasia cósmica y social, con su orgullo identitario» (Duviols: 1997, 293).

Los momentos del ritual descrito por Duviols a partir de las fuentes coloniales, refiere al solsticio de invierno, considerada como la del 'ciclo vegetal', "huarachicuy, fiesta mencionada en el mito, cuyos héroes, Pachacuti o Mayta Cápac, son elegidos gobernantes. $\mathrm{Al}$ mismo tiempo, en el mes de diciembre había rituales y ceremonias relativas a garantizar la fertilidad agrícola a cargo del «ayllu sacerdotal de los Tarpuntas (<tarpu- 'sembrar') se les ofrecía un bollo de maíz que, según parece, simboliza la buena cosecha y la reconciliación de los grupos provisionalmente marginados con respecto al Sol y los ayllus reales» (Duviols: 1997, 298). Se expulsaba y se reintegraba a los extranjeros en el Cusco mediante una reconciliación agrícola, por tanto, relacionada con Mayta Cápac. Pachacuti llevó a cabo una reorganización del ayllu de Alcauiza, y la fiesta solar, el Inti Raymi.

$\mathrm{Al}$ parecer todo apunta a un convivencia incaica y espacial de reunión en el solsticio de invierno, lo cual puede explicar de alguna manera la presencia de los rituales ${ }^{4}$ agrícolas por medio de enfrentamientos

4 Entiendo el ritual a partir de la propuesta de Rodrigo Díaz Cruz (1998), quien lo analiza como un espacio-momento de orden y unidad en un colectivo, lo que permite la socialización, delimitación de funciones y conformación de roles entre los miembros de la organización determinada. El ritual aparece así como procesos, funciones y formas simbólicas. Interesa seńalar que los rituales tienen un espacio y un tiempo establecido, es decir, como una fiesta que conmemora a 
socio-espaciales entre el hanan y el urin, o bien los gamonales y chinchilpos, que se presentan en el mes de enero en algunas poblaciones centroandinas.

El zumbanacuy ha sido clasificado por uno de los mayores estudiosos de la zona central andina, como una batalla ritual (Orellana 2007). Se trata de batallas o conflictos con marcado contenido territorial o de organización espacial del hanan-arriba y urin-abajo. También, se les denomina batallas rituales por su vinculación con la fertilidad de la tierra, en las cuales se enfrentan diferentes sectores de una misma población o de diferentes poblados en una lucha simbólica por el florecimiento de la tierra y la bonanza en las cosechas. Algunos ejemplos de esas batallas son mencionadas por Orellana (2007: 53): el Chiriaje, ${ }^{5}$ Canas, Cusco, se realiza el 20 de enero y el jueves de carnaval, un enfrentamiento entre la población como ritual agrario y de pago; en el mismo sentido, en Tocto, en la frontera de Canas y Chumbivilcas, Cusco, se lleva a cabo un enfrentamiento ritual, agrario y de pago; el takanakuy, enfrentamiento a golpes, se lleva a cabo en diciembre en Chumbivilcas; en Mudanza, Tupe, Yauyos, ocurre algo similar, limitado a un ritual agrario y de pago durante agosto y septiembre; el Lucheo, en Tomanga, Ayacucho, ocurre algo similar durante febrero y el carnaval, señalando el enfrentamiento como ritual agrario y de pago, entre otras confrontaciones que recuerdan la división territorial del hanan, arriba de los ricos, y el urin, abajo de los pobres.

Orellana atribuye al zumbanacuy un origen temprano, antes de la llegada de los espańoles, a la autoridad de grupos que sometieron al ayllu de Huayucachi, tal como la dominación huari, luego la yarovilca y posteriormente la inca, en la que el primero mantuvo relaciones de dependencia hacia aquellos y debido a

un santo, como el Tayta Nińo, que lleva a cabo una serie de acciones relacionadas con la fertilidad de la tierra. El zumbanacuy se presenta como la acción misma del ritual (Díaz Cruz, 1998, pp. 225-226), ya que se trata de un enfrentamiento entre los chinchilpos y gamonales, con fines agrícolas y de mantener el equilibrio en la misma población. A ello se le suma que genera orden, una puesta en escena, felicidad e infelicidad, por ejemplo en el caso estudiado una buena o mala cosecha, tienen una dimensión colectiva por poseer un significado social y se expresan de múltiples formas en sonido, vestimenta, máscaras, cantos alimentos, bebidas, etc.

5 Otros autores han mencionada sobre estas batallas o tinkuy, como un acto de complementariedad y oposición de las relaciones sociales andinas, por ejemplo Duviols (1997). Respecto al Chiriaje, como batalla ritual es de las más estudiadas, como acto de complementariedad y oposición en el cosmos y división socio-espacial andina; Brachetti (2001, 2005) y Lorente (2011), entre otros. esos conflictos pudo surgir el zumbanacuy (Orellana 2007: 62-63). No obstante que menciona que esos conflictos pudieron continuar en la Colonia, no presenta una argumentación mayor al respecto. En este sentido, relaciona el zumbanacuy al tinkuy o batallas rituales en la que los Yana Auka, los negros mayores o negritos bailarines, hacen un "sacrificio ritual de flagelamiento [...] están dando en ofrenda su sangre o su vida a la Pachamama para que ella retribuya, al ayllu o a la comunidad, con sus cosechas generosas y abundantes» (Orellana 2007: 57).

A su vez, relaciona el negro de la máscara que utilizan chinchilpos y gamonales a elementos simbólicos de posible origen huanca, en "raíces mágico-religiosas más profundas...» (Orellana 2007: 65) ${ }^{6}$, las cuales incluyen ofrecimiento de granos de maíz negro y coca en el templo de Chavín por parte de un Wari, referido a los huari asentados cerca de Huayucachi; sangre de llamas negras «... en un momento determinado, el sacerdote se cubría con la piel del animal sacrificado; posteriormente se utilizaron carneros negros. Los curanderos saben que el cuy negro es ideal para el jubeo» (Orellana 2007: 65) ${ }^{7}$. Sobre esta visión, se percibe el enfrentamiento con un origen antes de la llegada de los conquistadores y lo negro de la máscara del zumbanacuy en plena relación con elementos mágicos y rituales de la zona andina. Así, puede ser clasificada, a partir de la esquematización realizada anteriormente, como parte de esa visión de lo oscuro de origen andino, pero sobre todo no menciona la posible influencia de lo afrodescendiente. En este sentido, nuestra perspectiva suma el posible contacto colonial con la población afro, de grupos subalternos a la dominación española.

El zumbanacuy es una celebración en honor al Tayta Niño, niño dios patrón de Huayucachi, en la última semana de enero de cada año. Para la celebración, el pueblo se divide en dos bandos: el gamonal de

6 La yahuirca es el látigo o zumba utilizada por los chinchilpos y gamonales, en la que Orellana ve el otro elemento preincaico que «sobrevive» en la confrontación ritual. Sin embargo, es pertinente mencionar que el látigo fue un sino de dominación en la Colonia por parte de los españoles y de la población afrodescendiente al servicio de éstos.

7 El cuy es el conejillo de indias. En la actualidad en ciertas enfermedades, los terapeutas tradicionales utilizan un cuy negro para hacer el jubeo, pasar el animal sobre el cuerpo del enfermo. Una vez hecho esto, el cuy será sacrificado para que sea un medio de diagnóstico de la parte enferma de la persona. 
la zona norte, de los ricos, y el sur de los campesinos pobres o chinchilpos. ${ }^{8}$

\section{La presencia esclava africana en el valle del Mantaro}

Diferentes autores han probado fehacientemente la existencia del contacto étnico entre población afrodescendiente y andina en diferentes etapas de la historia del Perú. Inclusive, Olinda Celestino habla de un cierto descuido del tema entre los especialistas. Las relaciones de contacto entre población africana y andina se ubican en una época muy temprana de la Colonia.

En la primera etapa de la conquista, la población afro fue utilizada para conquistar, incluso se formó un batallón separado conformado por 40 negros, pero solo se dedicaron al pillaje, pero se marcó una fuerte comunicación entre los primeros africanos y la nobleza originaria andina (Celestino 2004a: 26 y 29).

El trabajo del esclavo pudo ser equiparado a la condición andina al trabajo del yana, personas que daban trabajo al incanato. La palabra yana refiere también al color negro o moreno en quechua, concretamente al campesino, el yana-runa (Celestino 2004b: 28; Flores Ochoa 2004: 59).

Por otro lado, se visualiza la presencia de afrodescendientes en los Andes con el Inca Tupac Amaru II, quien al rebelarse en 1780 contra los espańoles, quien tenía estrategas afrodescendientes, y junto a su esposa zamba abolió la esclavitud en el Perú de manera muy temprana. La población africana participó en las revueltas de la época colonial, asimismo participaron en el periodo de Independencia con el general San Martín y Bolívar (Celestino 2004b: 32). Sin embargo, la población afrodescendiente también cumplió ciertos papeles en la dominación y control de población andina. ${ }^{9}$

8 Sobre la palabra chinchilpo no se pudo ubicar un sentido etimológico, por el momento, pero es igualada a la de campesino o pobre. Sin embargo, refiere a «una hierba pequeñita, pero cuando tú lo dejas crecer se convierte en un arbusto y crece. Por eso es Chinchilpo. [..., pero a su vez] también Chinchilpo se le dice a las hormigas. La palabra chiquis también es una palabra quechua y chiquis es una hormiga pequeñita...» Roly Carhuallanqui, 23 de enero de 2014. La palabra gamonal determina la condición de rico o hacendado.

9 Rostworowski (2000, p. 32-33) ha señalado que la violencia de la población afro hacia la andina pudo deberse al sistema de violencia general promovida por la dominación española.
En la región de estudio, el valle del Mantaro, ha sido plenamente reconocida la permanencia y el paso de población africana en Jauja a partir del siglo XVII, pero no se descarta su presencia a mediados del XvI, al igual que en otros sectores de los Andes. Barriga (2008) prueba, mediante el archivo, la presencia de población afrodescendiente en el trabajo doméstico con los pocos españoles habitantes de la zona de Jauja así como en las casas de curacas o principales, como un símbolo de estatus. "Es necesario señalar que los esclavos eran señal de estatus, pues marcaban la diferencia entre ricos y pobres» (Barriga 2008: 46). El trabajo de la población esclava se destinó también a actividades ganaderas y como colaboradores en la hechicería. La población afrodescendiente fue escasa, una minoría que tuvo que adaptarse a las condiciones de vida de la población centroandina, situación que probablemente explique el por qué diferentes autores disminuyen o niegan la presencia afro en los Andes. Barriga proporciona una explicación al respecto: «Es así que los negros (incluyendo a las castas como mulatos o zambos) se asentaron como una minoría étnica en el valle» (Barriga 2008: 47) que rápidamente fue absorbida por la población andina. Respecto a las danzas, el autor señala la presencia de diferentes grupos cuyo origen deriva de esa presencia esclava africana, más aún si se considera que las llamadas danzas de negritos se presentaron en el mes de diciembre y enero, como la descrita más adelante, por el hecho de la liberación de esclavos en el mes de diciembre.

En otro sentido, la población afrodescendiente pasó en repetidas ocasiones por el valle del Mantaro. En un comunicado dirigido al general Daniel Florencio O'Leary, de origen irlandés, se le informaba de la presencia de "fuerzas que se hallan en las Provincial de Jauja de las tropas enemigas» respecto a diferentes contingentes formados por población afrodescendiente proveniente de Arequipa, en localidades cercanas a la de estudio, con "cuatrocientos negros» en Chupaca y «Cien morenos cazadores» en Chongo - posiblemente Chongos Bajo- (Noticias... 1882/1991).

Con lo anterior se prueba la permanencia de población afrodescendiente en el siglo XVII y posteriormente contactos efímeros o duraderos, se desconoce la forma, en el periodo de independencia en el siglo XIX, pero marcando la confluencia de sectores andinos y afrodescendientes, que muy probablemente 
compartieron no solo los genes, sino elementos culturales que hayan derivado en la influencia de algunas de las danzas con presencia en el valle del Mantaro.

Por otro lado, el decreto de abolición de la esclavitud firmado en Huancayo el 3 de diciembre de 1854 por Ramón Castilla, deviene de diferentes elementos históricos (Rodríguez Pastor 2005), entre los cuales destacan el propio clima de la época de bandos enfrentados, el de Castilla con José Rufino Echenique; las propias rebeliones de esclavos a lo largo de la Colonia; sectores peruanos e internacionales en contra de dicha práctica, entre otras, con lo cual se alude a una posible presencia afro y andina bajo esa condición en la zona de Huancayo, aunque el decreto, por supuesto, abarcaba a la gran presencia afro en la costa peruana.

\section{Las danzas andinas con presencia afrodescendiente}

En otro orden de ideas, en una esquematización tentativa surgida de la revisión bibliográfica de algunos de los materiales que tocan dicho tema, se pueden identificar, por lo menos, cuatro vertientes claramente establecidas para hablar de la presencia afro en las danzas de los Andes. Esta modesta esquematización es un primer intento de acercamiento al tema, por lo que no se puede hablar de esta propuesta cómo única o exclusiva, al contrario, constata la falta de análisis mayores para considerarla consolidada.

Una primera línea sostiene que en la cosmovisión andina se encuentran arraigadas presencias referidas a lo oscuro-negro. Se reconoce la articulación entre lo indígena-africano-español. Celestino (2004: 24) habla del Ccallac Pacha Tuta o Tutayacpacha, que en el origen es oscuridad, caos, desorden. Tutanquiri= Tut $a=$ negro=noche, como le llamaron a los negros; representarían a la noche en la visión andina. Es decir, en ésta ya existían nociones referidas a lo oscuro, que al contacto con los esclavos africanos le sumó al tutayquiris.

En los Andes, los españoles o Wiracochas, los africanos o Tutayquiris, los indígenas o Runasimis han llevado esos nombres quechuas desde el siglo xvI hasta hoy. Estos tres grupos sociales se encuentran en América del Sur y se teje entre todos ellos una relación de dominación y dependencia. La historia tradicional los separa fundándose en una lógica de castas que existía durante el período colonial. Algunas veces los tres grupos o más particularmente los africanos y los indígenas han establecido lazos estrechos que aparecen en la vida cotidiana, pues estos dos últimos grupos se encontraban en una situación subalterna. (Celestino 2004: 25)

En la cita de Celestino se percibe el entrecruzamiento de grupos diferenciados por su nombre, pero en el caso de los afrodescendientes, se percibe la referencia a la oscuridad con el color de piel de los esclavos traídos por los europeos. Al mismo tiempo señala la convergencia de los sectores étnicos en los Andes peruanos; entre ellos siempre existió una relación de dominación, lo español, y de subordinación, los africanos y la población andina, unos con mayor o menor grado de dominación dependiendo del tiempo histórico y los lugares, así como de las actividades productivas.

Lo relevante es mencionar que en la visión andina ya existían representaciones de la noche, por lo que los esclavos africanos fueron denominados "Tutayquiri, divinidades y personajes sagrados de la noche, de la obscuridad y de los abismos». En contraparte, los colonizadores «representaban a Wiracocha, símbolo de lo blanco y del día; el Dios tanto tiempo esperado que regresaba» (Celestino 2004: 25).

Entre los tres actores hubo intercambio cultural, incluso se le llama mestizaje, rebasando los límites de las castas. Entre africanos e indígenas hubo una mayor combinación genética por su condición subalterna, pero también por las condiciones de la sierra andina, donde los que estaban mejor adaptados al medio eran los originarios del continente. ${ }^{10}$

Una segunda versión de cercanía entre las danzas de negritos o con posibles reminiscencias de lo afro, se desprende de un elemento plenamente reconocido en la cosmovisión andina, la partición espacial en el hanan, arriba, y el urin, abajo, como formas de organización y relaciones sociales, de gobierno y

10 El cimarronaje, la huida de población afrodescendiente a la zona andina, también permitió el contacto entre esos grupos de población. Es pertinente mencionar que los esclavos arribaron a Perú por Panamá, por Brasil, por el Pacífico, Chile y Argentina, entre otros puntos. (Celestino 2004: 26-27), se extendieron en la costa sur (Chincha), la central (Lima) y la norte (Piura-Lambayeque) de Perú y algunos fueron trasladados a la sierra andina (Rocca 2010: 35). 
productivas en los ayllus. ${ }^{11}$ En este sentido, la parte de arriba, hanan, por lo general se identifica con sectores de población con mayores recursos, pudientes o adinerados, los gamonales en la actualidad; en tanto, la parte de abajo, urin, es señalada como el sector correspondiente a los campesinos, runas, pobres o chinchilpos, como los descritos más adelante. Diversos autores (Celestino 2000b: 51; Vásquez 2010: 78; Orellana 2007: 22) han identificado la presencia de esas particiones o mitades en los nombres mismos de las danzas.

Por su parte, Luis Millones hace una aseveración relevante sobre la continuidad de la cosmovisión andina. En la expresión dancística de los negros de Otuzco, Trujillo, Perú, los niños son ofrecidos a la virgen de la Concepción o "Mamita de Otuzco", que junto con el hanan-qapaq negro (rico) y los urinwaqcha negros (pobres), identificados como sus esclavos para servirle en la iglesia, especie de acólitos, transmite una tradición andina de «... dedicación o sacrificio de infantes es una constante. Las deidades de la región recibieron este tributo en ceremonias tan importantes como la Capac Cocha, muchas veces documentada» (Millones 2010: 121).

En ese mismo sentido, el trabajo de Chalena Vásquez (2010: 75-76), refiere a las diferentes danzas de negritos o negrería, pero coloca el acento en El Qhapaq negro. La autora habla de una recuperación de la danza, después de años de abandono, por lo cual la señala como una "invención de tradición", porque se retoma el nombre, pero se inventan los pasos y la música a partir de unos entusiastas a mitad del siglo pasado, aproximadamente en 1950.

Celestino refiere sobre esta misma danza, que $E l$ Qhapaq negro representa al esclavo que fue llevado a la zona andina a trabajar en las minas y los cocales. Su contraparte sería el Qhapac, proveniente de la palabra quechua para designar a un rico. Sin embargo, se debe ańadir que la estructura de la danza también

11 Véase el trabajo de Murra (2002), sobre la organización de los ayllus en el periodo inca, donde existía la división en los cuatro suyos, además de la división territorial arriba, hatun, y abajo, urin, la cual incluye una relación de subordinación entre curacas y los runas, los de poder y los campesinos, la clase alta y la baja. Rostworowski (1998: 25) ha señalado al respecto que la división en el hanan, arriba, y hurin, abajo, corresponde a una «... división dual en todo el ámbito andino" como complementos, pero con cierta "oposición relativa", marcando el ayllu, los pueblos y los valles. A esta división complementaria se le suman las nociones incas de icho y allauca, izquierda y derecha. representa el cosmos andino, en la división del arriba, hatun, y el abajo, urin, ya que se presume una posible división de la danza de negros en la antigüedad:

Parece que anteriormente existían dos grupos de danzas: Qhapaq negro y Waqcha negro, los ricos y los pobres; estos últimos utilizaban un vestuario sin bordados y como adornos llevaban rosarios; en cambio, los Qhapaq usaban vestuario de la mejor seda, con ceñidores en la cintura, ricamente bordados, cintas multicolores, hermosos detentes, monedas de plata, oro y pedrerías. (Celestino 2004: 51)

Con lo anterior se confirma una presencia de distribución espacial, como de la cosmovisión andina, arriba-abajo, hatun-urin, plenamente marcada por sectores de la población donde el rico y el pobre, en apariencia, aparecen reproducidos en la danza como en el espacio andino. Como se mencionará más adelante, en el zumbanacuy, pelea entre chinchilpos y gamonales, también reproduce esas esferas socio-espaciales del arriba-hatun de los ricos y el abajo-urin de los pobres. En este, el esclavo y el campesino andino, runa, comparten la condición social que los lleva a enfrentarse con los ricos. En la etnografía andina, es reiterada la división en el arriba y el abajo, pero resulta sorprendente que también la danza repita esa división espacial con características de ricos y pobres (Vásquez 2010: 78; Celestino 2004: 51).

Es decir, en las danzas también se extiende la tradición andina, tanto por su organización, en dos bandos o filas, o bien pertenecer a una tradición de lucha y confrontación entre esos mismo bandos, el bando de chinchilpos y gamonales, o bien los negros de Santiago de León Chongos bajos, o bien hananqapaq negro (rico) y los urin-Waqcha negros (pobres), que formarían parte de las luchas rituales de la vida andina de la que ha hablado Orellana (2007).

Una tercera visión sostiene que las ampliamente difundidas danzas de negritos o negrería en los andes peruanos, no tienen un sustento visible, o es muy escaso, de la influencia afro. Así, la visión de Rosa Alarco sobre la danza de negritos de Huánuco, Perú, visualiza influencias «europeas, árabes-españolas, religiosas, indígenas y alguna reminiscencia patriótica militar, tanto en la danza, música, como en el vestuario" (Parra 2009: 67), pero escasa influencia de lo afro. 
Por otro lado, una cuarta postura sostiene que las danzas de negritos en los Andes peruanos puede deberse al auge post independentista en el Perú, pero en ningún momento descarta los acercamientos culturales de afrodescendientes y población andina antes del siglo xix. Sostiene, por el contrario, que las danzas de negrerías se extendieron sobre todo en la época de la República, a la mayor parte del territorio peruano después de 1854 (Sánchez 2010: 18), ya que Ramón Castilla emitió un decreto el 3 de diciembre de ese ańo, que «... Proclama la libertad de todos los hombres que pisan el territorio de la República» (Sánchez 2010: 26). Esto explicaría la alta presencia de las fiestas de negrerías en el mes de diciembre, es decir, son navideñas o festejan al niño Dios, ya que por el decreto y la cercanía con las fiestas decembrinas, se acoplaron a ese calendario festivo.

Por otro lado, existe una vertiente más que habla de la presencia de lo afro en el Perú, cuya presencia se enmarca en lo afroperuano, no explorado en este trabajo, de las costas del pacífico con la plenamente identificada presencia de sectores afrodescendientes por medio de la herencia musical, dancística, literaria y de culto religioso por medio de cofradías, entre otros aspectos. ${ }^{12}$

Correspondiendo con esta tipificación provisional, este escrito promueve el enfoque de lo indoafrolatinoamericano, referente a las relaciones interétnicas complejas de los sectores afro, población originaria de los Andes y europeos en el conjunto de danzas, sin la intención de polemizar con alguna de las posturas anteriores, por el hecho de que cada danza en las distintas zonas de los Andes peruanos tuvo sus propias dinámicas de contacto entre afrodescendientes, población originaria y espańola o árabe, como lo menciona Alarco para los negritos de Huánuco, lo cual muestra un hecho decisivo: más que una unidad, se percibe una diversidad en la influencia o de orígenes en las llamadas danzas de negrería.

Por lo tanto, recurro a las palabras de los propios actores como elemento de identificación y filiación con los negros esclavizados en la región andina. $\mathrm{Al}$ respecto, el estudio de la oralidad se encamina al

$12 \mathrm{Al}$ respecto, existe una amplia bibliografía, pero resaltan algunos textos emblemáticos en los que se pueden encontrar las referencias para ahondar en este tema. Lo africano 2000; Rocca 2010; Schmidt 2006; Arroyo 2006; Melgar Bao 2013; Vásquez (s/f); Cairati 2011, entre otros. reconocimiento de los locutores como los protagonistas de su historia. ${ }^{13}$ Este trabajo coloca el acento en las voces de los protagonistas del zumbanacuy de Huayucachi, quienes identifican en una parte de su celebración ceremonial a los esclavos africanos, por medio de los negros mayores, como caporales tiradores de zumba, y a los negritos bailadores, como parte de la división socio-espacial del hanan-urin, arriba-abajodel centro andino peruano.

\section{El zumbanacuy de chinchilpos y gamonales de Huayucachi}

Existe una difusión de las danzas de negros o negrería en zonas andinas en las cuales aparentemente no hubo población esclava proveniente de África, o bien si la hubo no hay registros o faltan estudios con mayor sistematicidad para dar cuenta de ella. ${ }^{14} \mathrm{Tal}$ es el caso de la zona de estudio de este trabajo, región central del Perú, en el distrito de Huayucachi, cuyo origen es huanca, enemigos de los incas, posteriormente aliados de los españoles, pero donde al parecer no hay memoria de negros y la población es esencialmente descendiente del grupo originario de la región centroandina. Al respecto, coincido con Celestino cuando afirma que en poblaciones donde en apariencia no hay población negra, pero sí originaria y mestiza, las danzas de negritos "presenta el problema de la alteridad de la imagen del negro como lugar de identidad para los mestizos» (Celestino 2004: 51). En este sentido, considero que también es una alteridad para la población originaria, ya que ellos son los primeros artífices del manejo de la imagen de lo negro en sus danzas y música. Por ejemplo, en la danza de negritos de Huánuco, se visten de negro, pero la música, los movimientos, la música y la ritualidad asociada al niño Jesús son de carácter netamente originario de la zona andina. En el caso descrito a continuación, la

13 Véase Guiteras 1986; Molina Ludy 1990; Lupo 1995, entre otros, en la que los protagonistas de las historias son los propios actores y sus historias de vida hacen plausible entender una visión del mundo de distintos grupos originarios de Nuestra América.

14 «Negros, morenos o negritos son los apelativos más comunes de los conjuntos de danzantes que intervienen en la mayoría de festividades populares a lo largo de los Andes. No son descendientes de africanos, se trata de población de claro ancestro indígena que se disfrazan de negros. La mayoría de grupos de 'negros' que danzan o desfilan en las festividades reclaman como origen la presencia de los esclavos descendientes de africanos.» Millones 2010: 118. 
alteridad se percibe en la imagen del campesino pobre en situación similar a la del esclavo africano, no hay oposición étnica entre ellos, se percibe la alteridad en una condición de subalternidad. Esa alteridad también estaría dada entre estos grupos como pobres frente a lo adinerado representado por el gamonal.

Huayucachi es un distrito político de la provincia de Huancayo, del departamento de Junín, Perú. Habitado por descendientes de los huancas, como se mencionó al inicio de este escrito, grupo étnico con presencia anterior a los incas, aproximadamente del 900 d. C. a la conquista. Localizado en la zona centroandina del valle del Mantaro, a 3200 msnm, con población estimada de 8548 habitantes, en alto porcentaje dedicada a actividades agrícolas; posee una comunidad campesina, escasa industria, caracterizada por un comercio intenso con Huancayo, en productos como papa, trigo, cebada, maíz, alfalfa, alcachofa, entre otros.

En el ciclo ritual de Huayucachi, se pueden identificar tres grandes celebraciones festivas y dancísticas. La primera, y de mayor importancia económica y festiva, es la del zumbanacuy, realizada el último domingo de enero de cada año. La otra es el carnaval, con fecha variable dependiendo de la Semana Santa católica, cuyo eje es la danza del huaylarsh, de carácter agrícola, y bailado por diferentes comparsas integradas por mujeres y varones. La zona donde se asienta Huayucachi, se considera el origen de esta danza altamente difundida en la zona andina, pero con las dificultades de explorar con certeza dicho comienzo. Sin embargo, debe señalarse que las apropiaciones sobre esta danza y la gran cantidad de grupos o asociaciones que la bailan, incluso en Lima donde hay un concurso nacional, tiene claros tintes económicos y de prestigio. No obstante lo anterior, es una danza bastante extendida en la zona de estudio.

Los episodios dancísticos también se presentan con eventos religiosos como en la danza de Santiago, o de marcación ganadera, realizada en el mes de julio, ${ }^{15}$ y la celebración de las cruces, en honor al cerro San Cristóbal, sobre el cual se erige parte de la población de Huayucachi y que en últimos años ha perdido presencia por el privilegio del zumbanacuy y del huaylash de carnaval. ${ }^{16}$

15 Véase García Miranda, Juan José y Tacuri Aragón, Karlos (2006).

16 Estos aspectos los desarrollo de forma amplia en la tesis de doctorado, donde el zumabancuy se opone a la fiesta de cruces que fue im-
El zumbanacuy en que participan los negritos de Huayucachi, no refiere precisamente a una danza, no obstante el reconocimiento como tal de los propios participantes; es, como se ha mencionado antes, un enfrentamiento con un carácter eminentemente agrícola. La gente comenta que si el rico gamonal gana el enfrentamiento, en la población habrá hambrunas; si los chinchilpos, los pobres o campesinos ganan, la cosecha será abundante.

[...] manifiesta la tradición, de que si gana el chinchilpo la pelea va haber abundancia, si ganan los gamonales va haber sequía, hambrunas, etc. (Oscar Carhuallanqui, bando Chinchilpo, 4 de febrero de 2014)

Desprendido de lo anterior, se percibe el sustento andino como ritual de fertilidad, tal como los especialistas lo consideran, de enfrentamientos entre bandos del arriba y del abajo, como sectores que habitan el espacio andino.

Para establecer el ganador en la actualidad, la celebración marca diferentes elementos de calificación, ya plenamente determinados para evitar posibles conflictos entre los bandos. El aspecto esencial lo determina el zumbanacuy, es decir, la confrontación de los bandos por medio de la zumba, látigo pequeño elaborado de cuero vacuno con una base de madera. Otros elementos contabilizados para determinar el triunfo de uno u otro grupo, son el desfile inicial, la fama de las bandas de música contratadas, los castillones de los fuegos artificiales y un juego de fútbol, entre otros aspectos.

En el mito de origen de la celebración del Tayta Nińo, se visualiza un punto de encuentro entre la condición de los afrodescendientes, como esclavos, y la población andina en la misma situación, la subalternidad al dominante gamonal.

Acá la tradición de Tayta Niño de los negros, viene cuando menos de los años 1900, 1800, en la época del Virreinato. Acá usted verá una iglesia antigua. Es la iglesia en donde empezó la tradición de esta fiesta. Cuenta la leyenda que acá en Huayucachi había gente pudiente, que tenía esclavos, trabajadores, empleados, etcétera, que era lleno de ga-

pulsada por los adinerados de la población, por lo que se desprende que es una revuelta simbólica de los pobres contra los ricos. (García Torres: 2018, 288) 
monales. Por la historia se sabe que los gamonales son las personas pudientes que tienen mucho dinero, muchas extensiones de terreno y tienen sus obreros.

Entonces, en el distrito de Pallallá, que es de Huancavelica, también la gente era igual, y allí tenían una imagen y esa imagen se transformó en una paloma y vino para acá, a Huayucachi. Tanto permaneció acá sobre una roca, donde ahora está edificada esa iglesia antigua, que a una ancianita, una abuelita, se le revela en su sueńo y le dice la paloma "yo soy el niño Jesús», veo acá la gente muy pudiente, que no respeta, no comparte y yo quisiera quedarme acá en Huayucachi.

Hasta que un día dijo, al nińo no le gusta ninguna de estas danzas (referidas a las practicadas en el valle del Mantaro antes referidas). Hay que hacer otra danza nueva. Y entonces es ahí donde dice, porque no, si a nosotros nos castigan, nos hacen trabajar como peones, como esclavos, hay que rebelarnos en contra de los gamonales, hay que tirarnos zumba. Entonces es ahí donde empieza la tradición y el niño ya no se volvió a ir (Roly Carhuallanqui, bando Chinchilpo, 23 de enero de 2014) ${ }^{17}$.

En las palabras de Roly, como en la mayor parte de testimonios recabados, la situación de lo negro en Huayucachi es igualada a la esclavitud, condición de explotación padecida por los runas en los campos agrícolas de la zona. En este sentido, las posturas que señalan la inexistencia de población afrodescendiente en la zona, tiene que tomar otro rumbo, pues los descendientes huancas le han incorporado plenamente a su visión mítica, religiosa y ritual. Por este hecho, la convergencia afro en los Andes toma cabal presencia, no solo en el discurso, sino incorporado al mito antes mencionado y expresado por medio del zumbanacuy, en una confrontación en contra de los gamonales explotadores. Como lo mencionó Orellana, el zumbanacuy de Huayucachi representa esa sublevación contra el dominio huari e inca, antes de los europeos; después de estos, es probable que los huancas suma-

17 Un tema relevante desprendido de esta aseveración, es la relación de los mitos huancas relativos a la fundación de distintos pueblos, a partir de lagunas o piedras en las que se renuevan poblados y poblaciones, que a su vez reflejan cierta influencia católica de la destrucción de Sodoma y Gomorra. Este tema está en preparación a partir del mito centro andino de la fundación de pueblos, palomas y nińos como ejes de análisis. Es decir, de forma provisional se puede decir que el mito andino incorporó a su visión explicativa la presencia de población afrodescendiente, pero por el momento sólo puede quedar como una hipótesis en trabajo. ron al esclavo africano como su par en la explotación $y$ al europeo como el dominante.

La visión de los chinchilpos también es compartida por las personas integrantes del bando gamonal, los ricos, en cuanto a la salida de la esclavitud mediada por el zumbanacuy.

Bueno, eso es por la parte de ubicación [...] la parte norte, lo consideramos como gamonal. Y la parte sur la hemos considerado la parte, lo que nos representa a los chinchilpos. Entonces por eso es la división. [...] La palabra gamonal es siempre [...] justamente la que tiene dinero, como los gamonales de la parte pudiente. Ahora, por eso le dicen chinchilpo, es la parte de la clase baja y los gamonales de la clase pudiente, pero en realidad no es así. (En la actualidad) Somos iguales, por ejemplo en los chinchilpos hay personas que tienen más dinero que como le llaman los gamonales. Nosotros [los gamonales] somos gentes humildes, pero bueno lamentablemente representamos a la parte alta y los chinchilpos a la parte baja, pero bueno eso es en representación nada más [...] la palabra negro, creo que no siempre detalla la clase pudiente y la clase baja. De todos modos, anteriormente, ¿quiénes eran los esclavos? Eran los negros [...] a raíz de eso la palabra negro vamos a bailar, negros, entonces, para salir de la esclavitud.

[...] en este pueblo había un terrateniente, que era la familia Travezan [...] siempre ha existido como esclavo, los trabajábamos, mucha gente ha trabajado, porque ellos tenían tremendas extensiones de terreno. Siempre, la gente de aquí del pueblo de Huayucachi, hemos trabajado en su hacienda. Entonces, viendo toda esa situación, teníamos que salir de esa esclavitud. Porque ellos nos gobernaban, ¿por qué?, porque ellos eran pudientes, económicamente eran pudientes (Almicar Ferrer, bando gamonal, 29 de enero, 2014).

Como se puede apreciar en el testimonio del integrante del bando gamonal, también reconoce que lo negro se iguala a esclavo, es decir, la población campesina andina en igual condición de esclavitud, maltrato y pobreza por parte de los ricos de la población. Los negros, referidos a los participantes en el zumbanacuy, no obstante que no realizan una danza en sí en la fiesta, ${ }^{18}$ por medio del enfrentamiento buscan salir de la condición de esclavos.

18 El enfrentamiento entre chinchilpos y gamonales está considerada como una danza porque al inicio del desfile, hacen una coreografía marcada por movimientos lentos que resaltan el uso de la zumba 
Los chinchilpos, como se mencionó, son el grupo de personas pobres, campesinos o runas, ubicados espacialmente en el urin, el abajo, como una categorización socio-espacial. La referencia al bando gamonal, a pesar de que en la zona no hubo grandes haciendas, refiere a los hacendados, a los ricos o adinerados, como sucede en otras áreas del Perú o de América del sur. Quijano (2007: XXII) ha sostenido que los gamonales incluyen al gran hacendado, pero también a curacas locales o campesinos ricos, intermediarios del poder nacional, en los ámbitos político y económico que contribuyen a la dominación de la «burguesía imperialista» peruana. Los gamonales pertenecen al hatun, el arriba socio-espacial. En este sentido, el barrio es una denominación plenamente de origen español, no obstante, se percibe la gran influencia del espacio de la cosmovisión andina, como se señaló anteriormente.

Los chinchilpos usan el color rojo en el casco, en una especie de corbata y en la chompa (suéter), como tono diferenciador. Por su parte, los gamonales visten igual, pero con el celeste (azul) en el casco, listones y bufandas; su chompa es blanca. ${ }^{19}$ Ambos grupos completan su vestimenta con uno de los aspectos que refiere a lo afro, su máscara de color negro, hecha de piel de vacuno, pintada de negro y adornada con

o el látigo. Sin embrago, dichos pasos marcan su incorporación al conjunto de danzas de la zona andina de Huancayo. Resulta que esos pasos se dejaron de hacer hace algunos ańos, pero hoy la junta directiva de los bandos gamonal y chinchilpo los están reviviendo porque están buscando el reconocimiento por parte del Ministerio de Cultura como danza patrimonio cultural del Perú, pero para ello requieren contar con una coreografía. De ahí su intento de revivirlos del abandono. Es probable, también, que la referencia como danza se encuentre en la parte del desfile en la que reproducen danzas de la zona centro andina, como se describirá después, ya que los negros bailadores reproducen éstas en forma de sátira, pero cumpliendo los movimientos y los vestuarios de las representaciones de las que se burlan.

19 Además de lo ya señalado, ambos bandos visten con pantalones blancos, capote negro, que recuerda una especie de capa que cubría a los policías de la guarda civil a mediados del siglo pasado; botas tipo militar en color café. El casco es adornado con la crin de caballos. Oscar Carhuallanqui especificó que la homologación de colores es reciente, a partir de 1968; anteriormente, las empresas de transporte público contribuían a la fiesta, y los "gladiadores", como también se les llama a los participantes del combate, utilizaban diferentes colores, incluso los de los autobuses patrocinadores. El color rojo de los chinchilpos también ha sido identificado como un color simpatizante de los movimientos revolucionarios de América Latina y la influencia del Che Guevara; además, la bandera del bando es acompañada con color negro, que remite a la bandera de huelga. Estos datos son relevantes para el trabajo doctoral, pero por las intenciones de este escrito, no serán desarrollados aquí, pero refieren a una revuelta simbólica del grupo subalterno, chinchilpo pobre, contra el grupo dominante, el gamonal rico. múltiples diseños de barba negra o de color rojo o celeste, según los integrantes de cada sección.

En palabras de Almilcar Ferrer, del bando gamonal, señala claramente la pertenencia a un bando:

[...] por la parte de ubicación que tiene el pueblo de Huayucachi. Este centro es Huayucachi, esta parte más o menos de barrio Centro, barrio Yacus, barrio Libertad, barrio Manya, barrio Chanchas, barrio Huanmamarca casi a la parte norte, lo consideramos como gamonal. Y la parte sur la hemos considerado la parte, lo que nos representa a los Chinchilpos. Entonces por eso es la división. Esta parte del norte es gamonal y la parte sur es los Chinchilpos (Amilcar Ferrer, 29 de enero de 2014, bando gamonal).

Los barrios del bando chinchilpo son los de Quillispata, Colpa Alta, Colpa, Miraflores y Mantaro. Orellana (2007: 63) ha señalado apellidos plenamente reconocidos para el bando gamonal, como Travezan y Montes de Oca, el primero como el gran terrateniente de Huayucachi a finales del siglo xIx y en la primera mitad del siglo xx. El bando chinchilpo estaría integrado por apellidos como el de la familia Carhuallanqui. En este sentido, es importante mencionar que el barrio gamonal está identificado por apellidos hispanizados o de probable origen español y también por apellidos de origen quechua como Unsihuay, mientras el barrio pobre o chinchilpo por apellidos huanca-quechuas. ¿Se trata de un enfrentamiento étnico, entre descendientes espańoles o curacas españolizados y los runas pobres? ¿Los apellidos Travezan y Montes de Oca, del norte-hatun, y el de Carhuallanqui, del urin-sur, son indicadores de pertenencia étnica? En este momento de la investigación es imposible contestar dichas preguntas, pero lo evidente es que se hace presente la división socio-espacial andina, en el norte-hatun los ricos-gamonales y los chinchilpos pobres en el sur-urin.

La fiesta en honor al Tayta Niño integra personajes como el Prioste (mayordomo), caporales por bando, encargados de apoyar a los negros de su organización, los simpatizantes de estos y los negritos. La víspera de la fiesta inicia el jueves último de enero y se extiende al sábado. El domingo y lunes serán los días principales del zumbanacuy y las invitaciones comienzan el martes y duran unos cinco o seis días. A continuación 
se describirán brevemente para llegar, así, a la participación de los negritos en el zumbanacuy.

La fiesta patronal en honor al Tayta Niño está organizada por el prioste (mayordomo), su familia y amigos, en quien recaen los gastos de la celebración como los de animación musical, banda de viento, las ropas del nińo-santo, la comida ofrecida el domingo con la cual oficialmente se inicia la celebración, los fuegos artificiales y otros gastos como animadores y adornos de la iglesia. El prioste también está afiliado a uno de los bandos, rotado cada año entre chinchilpos y gamonales. En el año 2014, el prioste perteneció al bando chinchilpo. En una escena paralela a la de organización del prioste, se encuentran los caporales por barrio, personas que ocupan el puesto por un año y que tienen como fin apoyar al bando al que pertenecen, pero también como un acto de solidaridad por los gastos de la fiesta hacia el prioste y su grupo de simpatía. Así, por cada barrio hay mínimo tres y hasta once caporales; por ejemplo, para el bando chinchilpo hubo 30 caporales en el año 2014, quienes participan activamente en la fiesta, pero sobre todo después de concluida la celebración oficial, como se describirá más tarde.

La Víspera se refiere a la celebración previa al último domingo de enero, dividida en tres días, jueves para chinchilpos, viernes para gamonales y el sábado corresponde al prioste. De manera general describiré algunos elementos de estas, ya que el sábado se hace la elección de Negros mayores por bando.

La Víspera del bando chinchilpo, arranca la celebración el día jueves. Ellos se encargan de vestir al Tayta Niño y de adornar el interior de la iglesia con flores de color rojo. Posteriormente, hacen una procesión por la noche en la que desfilan sus simpatizantes, mayoritariamente vestidos con prendas rojas y flores del mismo color. Son acompañados por una o dos bandas de viento por las calles de la población, hasta llegar a la iglesia, en la cual el sacerdote oficiará una misa para dicho grupo. ${ }^{20} \mathrm{Al}$ terminar la celebración

$20 \mathrm{Al}$ respecto, vale la pena mencionar que la propia configuración del interior de la iglesia, marca la división de los dos bandos. El lado norte de ésta tiene un altar pintado con motivos de color azul que corresponde al bando gamonal. El lado sur tiene su altar con colores rojos. Esta iglesia es reciente, la iglesia antigua, señalada anteriormente en el mito de origen del Tayta Niño, ahora está en ruinas, sólo queda el campanario, algunos muros y la fachada en pie. Esta iglesia está más cargada hacia el lado sur, del barrio chinchilpo y ha sido denominada por Orellana (2007: 30) como la huaca, centro ceremonial de los huancas antes de los espańoles. religiosa, se lleva a cabo una convivencia en el atrio de la iglesia y la Plaza de Armas de la localidad, en la que participan ambos bandos, pero de nueva cuenta se percibe la competencia musical, ya que cada uno de ellos tiene su propia banda de viento que acompaña los huaynos; se toma cerveza, calientito, bebida de aguardiente o pisco con hierbas, y se baila al ritmo del artista musical contratado por el bando para animar la convivencia. El día viernes, corresponde al bando gamonal organizar su propia víspera, similar a la descrita anteriormente.

El prioste tiene a su cargo la víspera central, el día sábado, ya que se encarga de vestir al Tayta $N i n ̃ o o^{21}$ con los colores rojo y celeste de cada bando, chinchilpo y gamonal respectivamente; organizar la misa; la quema de castillones y el baile general en la plaza pública de la localidad.

Un acontecimiento que refiere a la cuestión afro en la celebración, se lleva a cabo precisamente en la víspera general, el sábado por la tarde-noche, en el interior de los locales que cada bando. Se trata de la elección de los negros mayores y de la Junta Directiva de cada bando. Describiré brevemente la presenciada en local de los chinchilpos; al mismo tiempo los gamonales hacen por su parte la actividad similar. Los cargos, antes mencionados, tienen duración de un año y empiezan en función inmediatamente, después de ser elegidos, ya que estarán a cargo de la zumba al día siguiente.

En una plenaria en la cual participan los integrantes y simpatizantes chinchilpos, tanto de los residentes de Huayucachi como de los provenientes de Lima o de otras localidades donde han migrado a trabajar, la junta directiva saliente rinde cuentas del capital y de las acciones realizadas, lo cual está lejos de ser una reunión idealizada. Se identifican cuasi grupos, algunos simpatizantes o detractores de quienes tienen el mando al turno; se despliegan críticas de las acciones de la junta en turno e incluso se cuestionan los gastos de los recursos económicos recabados en la fiesta

21 La participación de las mujeres en la celebración se despliega en aspectos como el apoyo al esposo o hijos, en el acompańamiento a los diferentes momentos de la fiesta, pero sobre todo el apoyo el día de la tirada de zumba, ya que curan, de ser el caso, cualquier herida provocada por la batalla; o bien preparar los platillos regionales que se comparten en la víspera del sábado. En este sentido, el zumbanacuy es un acto eminentemente masculino, porque son ellos los protagonistas del enfrentamiento. La vestida del Tayta Niño es una actividad plenamente femenina, mujeres de ambos bandos acompañan al Prioste y su esposa a cambiar las ropas del santo patrono. 
anterior. Como se mencionó antes, el pertenecer a un bando está determinado por la pertenencia a uno de los barrios de la división hatun y urin, pero también se presentan los casos al interior de una misma familia que los integrantes por voluntad propia determinan su simpatía por el bando distinto de donde nació. Al mismo tiempo, hay cambios de adscripción de bando, incluso entre los Negros Mayores se llega a cambiar cuando se ha tirado zumba para uno de los bandos por varios ańos, pero se hace por mantener privilegios como salir número uno en la batalla, conservando el rango de Negro Mayor.

$\mathrm{Al}$ turno de elegir a los negros mayores, los cuasi grupos despliegan también sus simpatías por quienes han demostrado un manejo del látigo efectivo para vencer a sus rivales y realizan una votación para determinarlos. El resto de participantes en la celebración, son identificados como negritos bailadores. ${ }^{22}$ En este sentido, independientemente de que haya habido o no esclavos en Huayucachi o la zona de Huancayo, que los hubo, la población andina se representa a sí misma como negro, no obstante el bando rico o pobre, pero que remite a una convergencia de lo afroindolatinoamericano mencionado con anterioridad; es decir, a una relación marcada por los contactos entre población africana, andina y europea a partir de sus propias palabras, como en los testimonios anteriores, o sus propias denominaciones, como negro mayor y negrito bailador.

A los negros mayores, les corresponderá la responsabilidad de participar en los primeros turnos del látigo o zumba, la pelea entre estos y los gamonales, el orden y la organización de los grupos de danzantes en el desfile, así como en los turnos de participación en la zumba. Aquí el negro es la alteridad de fuerza, de valor y de dominio de la zumba (látigo), así como su capacidad de evasión de los golpes del negro contrario.

Sin embargo, también es pertinente hacerse algunas preguntas sobre la identificación de la población africana como capataces en la Colonia en distintas zonas andinas y costeras del Perú: ¿El negro mayor es una herencia de los afrodescendientes caporales de la

22 En cada uno de los bandos, se asumen como negritos bailadores más de 300 personas, sólo hombres, pero en la zumba presenciada sólo participaron poco más de doscientos. El número de participantes también ha ido en aumento ańo con ańo de la fiesta, como lo marcan las etnografías antes mencionadas.
Colonia? El látigo utilizado en la zumba, ¿̇representa la figura del capataz afrodescendiente que controló a la población andina en el cultivo de la tierra y el trabajo en las minas? Lejos estoy de proponer si quiera alguna hipótesis al respecto, pero es importante considerarlas para futuros estudios de mayor profundidad.

Quienes salieron elegidos negros mayores y negritos bailadores, tienen la obligación de pagar económicamente a las autoridades del distrito o del bando, el derecho de participar en el zumbanacuy.

El domingo inicia oficialmente la celebración del Tayta Niño, con una procesión en la que cada bando, organizados en dos filas separadas, pasean al santo patrón por las calles del pueblo. ${ }^{23}$ Posteriormente, el prioste ofrece un almuerzo de camaradería al cual se integran chinchilpos y gamonales, simpatizantes y espectadores en general. Al terminar este, se realiza el desfile, el cual forma parte de la competencia oficial, en el que cada bando reproduce a manera de sátira, las diferentes danzas del valle del Mantaro. No obstante de que las danzas originales integran mujeres a su elenco, los varones de ambos grupos asumen la vestimenta y roles de estas. De nueva cuenta, el bando chinchilpo inicia el desfile de corte militar, solicitando permiso a las autoridades locales, los jueces encargados de calificar a los bandos participantes y el prioste, para iniciar la marcha. Los gamonales harán lo mismo por su parte.

Terminado el desfile, ambos grupos se dirigen al estadio de Huayucachi, donde se cobra la entrada de cinco soles, ${ }^{24}$ para iniciar el partido de fútbol, en el

23 Orellana (2007: 24) ha mencionado la probabilidad de que la organización de los dos bandos, gamonal y chinchilpo, tenga una reminiscencia en las cofradías fundadas durante la Colonia. Éstos eran grupos con tintes religiosos que tuvieron a su cargo secciones de terreno para sembrar y subsanar los gastos de la festividad. Este dato es importante para el enfoque afroindolatinoamericano, ya que Arroyo (2006) y Rocca (2010), han seńalado que las cofradías en distintos lugares del Perú, pero esencialmente en Lima, estuvieron conformados por población afrodescendiente para los cultos del Cristo Negro, seńor de Pachacamilla. Con ello, no se afirma el mismo proceso para Huayucachi, pero si puede ser un dato que coloque el acento en las cofradías como una probable reminiscencia del contacto de población afro y originaria andina; tal como lo señalan también otros autores, por ejemplo, Panfichi, Aldo (2000).

24 Los recursos recabados por el cobro al estadio, al inicio de la década de los 70 del siglo pasado, se dividen entre un $40 \%$ para chinchilpos, otro similar para gamonales, y un $20 \%$ para la iglesia. Este cobro ha permitido a cada bando contar con sus respectivos locales donde llevan la selección de las mesas directivas y de los negros mayores. Esos porcentajes se incrementan para cada bando, por el cobro de los negritos bailadores, o zumbadores, que pagan el derecho de combatir. 
cual los integrantes participan con la máscara negra y el vestuario antes descrito. El resultado del juego también es contabilizado para determinar a la sección ganadora.

$\mathrm{Al}$ respecto, las etnografías sobre chinchilpos y gamonales, ${ }^{25}$ y la propia observación en el año 2014, refieren una gran movilidad de la celebración religiosa y de la incorporación de varios aspectos de la vida nacional del Perú. La música de la banda de vientos andina; las botas de tipo militar; el capote de la policía civil del Perú de los años 50 del siglo pasado; el cobro por presenciar el zumbanacuy; el incremento de los días de la celebración, antes de los 90 del siglo pasado únicamente había una víspera; el cambio de sede del enfrentamiento del atrio de la iglesia antigua al estadio distrital y el incremento del número de $n e-$ gros mayores (en los setenta solo había uno y en la actualidad hay diez por cada bando), entre otros aspectos, no considerados por el momento en este estudio, forman parte de esa flexibilidad de la celebración para incorporar aspectos de su entorno. En este sentido, el partido de fútbol realizado como el preámbulo del zumbanacuy, también es una incorporación reciente, incluso Orellana lo menciona en el registro de los años 70 que hizo de la celebración, como «Todo un espectáculo es el partido de fútbol entre chinchilpos y gamonales. Esto no forma parte de la estructura ritual del zumbanacuy» (Orellana 2007: 47). En la actualidad, el partido es uno de los espectáculos principales e incluso forma parte del puntaje que determina al bando ganador.

El zumbanacuy o la tirada de látigo es el evento esencial, que comprende el domingo y el lunes. Consiste en una actividad de contacto y de fuerza, ya que los negros mayores y negritos bailadores se enfrentan entre sí, con una duración de 30 y 20 segundos, respectivamente, cada uno compitiendo por su bando gamonal o chinchilpo. En la actualidad, las juntas directivas de los bandos buscan imparcialidad para determinar a los ganadores, por ello recurren a la Policía Nacional del Perú, para que estos funjan como jueces del enfrentamiento.

El ganador en la zumba se determina por propiciar mayor número de latigazos al adversario y mostrar agilidad al evadir los del contrario, pero el triunfo

25 Véase Maldonado Palacios (1972); Chávez de Paz (2005); Manrique y Unsihuay (1999); Orellana (2007). es inobjetable cuando uno de los peleadores logra derribar al contrario. Los oficiales de la policía controlan el tiempo y al finalizar la pelea, uno de ellos levanta un casco del color del ganador, rojo para chinchilpo y azul (celeste) para el gamonal, o bien ambos para determinar un empate. En el año 2014, participaron más de doscientos gladiadores por bando, como le llaman a los negritos, divididos en enfrentamientos con más de tres horas de duración el domingo e igual número de tiempo el lunes. Los negritos entre sí desconocen la identidad de su adversario, ya que portan la máscara que alude a lo afrodescendiente. Sin embargo, como se establece una lista en el orden de participación, incluso hay negritos que negocian su lugar para poder confrontar a alguna persona determinada, por lo tanto, la zumba también se convierte en un escenario para dirimir conflictos personales o sociales, pero los cuales quedan reducidos solo a los latigazos, por lo que ganar y perder no conlleva a la extensión de peleas posteriores a la celebración.

El lunes de fiesta principal inicia con una ceremonia religiosa en la que participan chinchilpos y gamonales, ulteriormente vuelven a desfilar al estadio en compañía de sus simpatizantes. Después de mediodía, comienza de nuevo el zumbanacuy, en el que se vuelven a enfrentar los bandos por más de tres horas, con el resto de negritos bailadores pendientes por pelear. Al finalizar la confrontación, los jueces anuncian al ganador. En la confrontación presenciada, los chinchilpos fueron ganadores, con lo cual se esperó que la cosecha del año 2014 fuese abundante, pero también se determina un prestigio social por parte del grupo vencedor, pues este es reconocido en el ámbito social mayor de Huayucachi.

Terminada la publicación del ganador en la zumba, cada bando ameniza su propia fiesta con las bandas de viento contratadas para la ocasión, al mismo tiempo inicia un último acto musical contratado por el prioste, el cual marca el fin del zumbanacuy.

El día martes inician las invitaciones o el cambio de caporal. Las invitaciones es un acto de reciprocidad social, el cual está dado por ambos bandos. Los caporales de cada uno de estos, organiza, por su cuenta, una celebración extendida por seis días más, cuya finalidad es, en primer lugar, hacer el cambio de caporales de cada uno de los bandos. En palabras de Orellana Valencia (2007: 49): 
[...] el cambio de caporal (también denominado caporía); esto consiste en la visita a diferentes casas de chinchilpos y gamonales, en las que se eligen nuevos caporales, mediante la entrega de un cuchiponte (chancho [cerdo] asado) y todo tipo de bebidas.

En las invitaciones, los caporales hacen entrega de una comida especial, una especie de reconocimiento a los negritos de su bando por la disputa en el zumbanacuy.

Los negros mayores vuelven a ser protagonistas de la actividad, ya que los caporales les entregan a ellos los alimentos, cervezas y chicha a repartir entre los negritos bailadores del bando. Ellos dosifican el alimento y la bebida en las dos horas que dura la invitación, terminada esta deben regresar vacíos los utensilios en los cuales les fue compartida la comida y bebida. Por día se celebran aproximadamente cinco invitaciones, a las que poco a poco se integran los negritos bailadores y los simpatizantes para compartir los alimentos y bebidas.

De esta forma termina la fiesta religiosa y ritual del zumbanacuy en honor al Tayta Niño, en la cual se percibe que los chinchilpos y gamonales remiten a dos sectores antagónicos en la sociedad andina. Los pobres, trátese de población originaria, o negros o mestizos, que no tienen propiedad y están bajo la servidumbre del señor gamonal, el patrón, el rico y dueño de las tierras.

\section{A manera de conclusión}

Lo afirmado hasta ahora está lejos de considerarse una interpretación final sobre el zumbanacuy. Es, por decir lo menos, un inicial acercamiento a la complejidad de las relaciones y convergencias étnicas en los Andes a partir del enfoque afroindolatinoamericano, el cual busca identificar esas relaciones de acercamiento más que poner el acento en las diferencias.

El zumbanacuy es un ritual agrario ubicado en el mes de enero que coincide con la descripción de Duviols sobre el ciclo vegetal dado en los meses de diciembre, coincide con el solsticio de invierno, y enero, una plena continuación de los aspectos andinos.

Las palabras de los protagonistas del zumbanacuy dejan huella clara de la visión de los runas-campesinos de la zona centroandina sobre la población afro- descendiente: se les ubica como esclavos y al mismo tiempo en una situación similar de explotación. La filiación de la población andina con el esclavo y con los campesinos de la zona baja del urin, permite observar la convivencia de ambos sectores, ya sea plenamente por el contacto permanente o transitorio, bajo una misma condición que los lleva a enfrentarse al grupo dominante, identificado aquí como el de los gamonales. Así, el zumbanacuy es una forma de liberarse de los gamonales mediante la lucha a través de los latigazos.

Al mismo tiempo, refiere a una visión sobre la fertilidad de la tierra. El triunfo de los chinchilpos da certeza sobre la abundancia de la cosecha, pero de ganar el gamonal, la baja productiva marcará el destino de los campesinos. De tal forma, se puede aventurar que el enfrentamiento de los ricos y los pobres, plenamente reproducida por la visión socio-espacial andina, incorporó la noción del esclavo y la población originaria andina de Huayucachi en una revuelta contra la dominación de lo europeo-mestizo-rico como el explotador y esclavista.

En el mito sobre el origen de la fiesta del Tayta Niño, la danza de chinchilpos y gamonales se percibe que los participantes de la parte baja o sur, el urin, correspondiente a los campesinos pobres identificados como esclavos, en igual condición que los afrodescendientes, salvan al pueblo de la esclavitud a la cual son sometidos por los gamonales por medio de un enfrentamiento que también tiene su realización en el ritual agrario de abundancia de cosecha. En este sentido, el mito incorpora la alusión a la población afro y campesina en un proceso de liberación.

Compartimos la visión de los expertos en el sentido de que en la batalla de chinchilpos y gamonales hay evidencias claras de una visión andina sobre lo oscuro, como el color de la máscara que portan, los aspectos mencionadas por Orellana en cuanto al aspecto ritual que tuvo el color negro en la historia de los huancas. Pero al mismo tiempo consideramos que esa presencia y la plena alusión a los esclavos, muestran la concurrencia de diferentes sectores étnicos en la sierra andina con la llegada de los invasores europeos después la conquista en los Andes.

Las voces de algunos de sus protagonistas y la utilización de la máscara, claramente aluden a una población afro que, de manera tangible o ficticia, participa de la esclavitud, condición de subalternidad 
compartida por la población andina bajo las condiciones de explotación de los curacas o campesinos ricos, identificados con el nombre de gamonales. Es decir, la autoidentificación como negros mayores o negritos bailadores, pone en juego la visión de la alteridad que ha mencionado Celestino, en la cual se iguala al esclavo africano con la de la población originaria de los Andes.

Se trata, al mismo tiempo, de una revuelta simbólica contra los caciques centroandinos, protagonizada en el zumbanacuy, en el cual el objetivo es que gane la clase subalterna, los negritos o runas andinos, percepción que conduce a lo negro y chinchilpo como representación de la pobreza.

Faltan mayores elementos de investigación, algunas preguntas ya planteadas, acerca de la posibilidad de considerar el papel de los negro mayores como los capataces de los campesinos andinos durante la Colonia, por lo tanto no debe perderse de vista que quedan más preguntas que respuestas definitivas sobre las relaciones de la población afrodescendiente y originaria en los Andes peruanos.

\section{Bibliografía}

Alarco, Rosa (2010). Los Negritos de Huánuco en «La negrería en el Perú». Folklore. Arte, cultura y sociedad, Revista del Centro Universitario de Folklore. Universidad Nacional Mayor de San Marcos, Año 1, Número 2, Noviembre, pp. 127-178.

Arguedas, José María (1957a). El valle del Mantaro y la ciudad de Huancayo, un caso de fusión de cultura no perturbada por la acción de las instituciones de origen colonial. Tesis de bachiller, Universidad Nacional Mayor de San Marcos, Facultad de Letras, Instituto de Etnología.

Arguedas, José María (1957b). Estudio etnográfico de la feria de Huancayo. Lima: Oficina Nacional de Planeamiento y Urbanismo.

Arroyo Aguilar, Sabino (1987). Algunos aspectos del culto al Tayta Wamani. Lima: Universidad Nacional Mayor de San Marcos, Seminario de Historia Rural Andina.

Arroyo Aguilar, Sabino (2006). Formas de vida e integración de los afroperuanos de hoy. En Investigaciones Sociales, Año X N ${ }^{\circ} 16$, Universidad Nacional Mayor de San Marcos, Instituto de Investigaciones Histórico Sociales, Lima.
Arroyo Aguilar, Sabino (2008). De Santiago Mataindios a Tayta Shanti. En Revista de Antropología, Año VI, N. ${ }^{\circ}$, diciembre, Perú, Universidad Nacional Mayor de San Marcos, pp. 119-134.

BARriga, Eduardo (2008). 'Ser negro en pueblo de indios': Los esclavos del valle de Jauja del siglo xvir. En Anthropia, Revista de antropología y otras cosas, N. ${ }^{\circ} 6$, Facultad de Ciencias Sociales, Pontificia Universidad Católica del Perú, Lima, pp. 45-48, p. 46.

Brachetti, Angela (2001). La Batalla de Chiaraje: Una pelea ritual en los Andes del sur de Perú. En Anales del Museo de América, No. 9, pp. 59-78, Museo de América.

Brachetti, Angela (2005). El año en fiestas. La convivencia con los dioses en los Andes del Perú. Lima: Museo de América-Ministerio de Cultura-Museos Estatales.

Cairati, Elisa (2011). «AfroPerú: Tras las huellas de la negritud en Perú». En Altre Modernitá, Saggi N. 6-11, Universitá degli Studi di Milano-Facoltá di Lettere e Filosofia, pp. 121-138.

Celestino, Olinda (2004a). Los afroandinos y la 'ruta del esclavo'. En Los afroandinos de los siglos XVI al XX. UNESCO, Perú.

Celestino, Olinda (2004b). «Relaciones incas-negros y sus resultados en el capac-negro y los negritos». En Los afroandinos de los siglos XVI al XX. UNESCO, Perú.

Chávez de Paz, Darío (2005). Chinchilpos y Gamonales. Huayucachi. Lima: Centro Peruano de Estudios Folclóricos.

Duviols, Pierre (1997). Del discurso escrito colonial al discurso prehispánico: hacia el sistema sociocosmológico inca de oposición y complementariedad. En Boletín Francés de Estudios Andinos, 26 (3), pp. 279-305, Lima.

Enríquez Bergna, Luis E. (2011). La Huaconada. Danza ritual del pueblo del mito... Patrimonio Cultural Inmaterial de la Humanidad (UNESCO). Lima: Universidad Nacional Mayor de San Marcos.

Espinoza Soriano, Waldemar (1971). Los Huancas aliados de la conquista. Tres informaciones inéditas sobre la participación indigena en la conquista del Perú 1558-15601561. Huancayo: Universidad Nacional del Centro del Perú.

Fiesta en los Andes. Ritos, música y danza del Perú (2008), Instituto de Etnomusicología PUCP-Fondo Editorial Pontificia Universidad Católica del Perú.

Flores OchoA, Jorge (2004). Yana y negro en la región sur andina. En Los afroandinos de los siglos XVI al XX, UNESCO, Perú. 
García Miranda, Juan José y Tacuri Aragón, Karlos (2006). Los rostros de Santiago: patrón, ganadero, callejero. Estudio de las fiestas patronales de Chongos Bajo $y$ del ganado en el Valle del Mantaro. Quito: Instituto Iberoamericano del Patrimonio Natural y CulturalConvenio Andrés Bello-Proyecto Cartografía de la Memoria.

García Torres, Víctor Manuel (2018). Etnoterritorio en la Sierra Norte de Puebla, México, y la Sierra Central, Perú. Tesis de Doctorado en Estudios Latinoamericanos, Facultad de Filosofía y Letras, Universidad Nacional Autónoma de México.

Gramsci, Antonio (1975). Cuadernos de la cárcel: Los intelectuales y la organización de la cultura. México: Juan Pablos Editor.

Guiteras Holmes, Calixta (1986). Los peligros del alma. Visión del mundo de un tzotzil. México: Fondo de Cultura Económica, Sección de obras de Antropología.

Hurtado Ames, Carlos H. (2013). ¿Huanca o Xauxa? Los grupos étnicos prehispánicos y la invención de la historia en la sierra central del Perú. En Historia y Región 1, año I, octubre, pp. 221-242.

Lo africano en la cultura criolla (2000). Fondo Editorial del Congreso del Perú, María Rostworowski, Javier Mariátegui, Carlos Aguirre... [et al.]; presentación de Martha Hildebrandt, Lima, 2000, Perú.

Lorente Fernández, David (2011). La violencia del Estado como chiaraje o guerra ritual: una interpretación cosmológica de la lucha del ejército contra los quechuas de Sicuani en el sur del Perú. En Revista Española de Antropología Americana, España, Vol. 41, núm. 2, pp. 547-568.

Lupo, Alessandro (1995). La tierra nos escucha. La cosmología de los nahuas a través de las súplicas rituales. México: Consejo Nacional para la Culturas y las Artes-Instituto Nacional Indigenista.

Maldonado Palacios, Eulogio (1972). Huayucachi. Estudio monográfico. Lima: Edición del autor.

Manrique Unsinuay, Ronald y Estela Unsinuay Vila (1999). Guía de preparación fisica para desarrollar las cualidades fisicas de los participantes de la estampa costumbrista de los chinchilpos y gamonales de Huayucachi. Huancayo: Universidad Nacional del Centro del Perú.

Melgar BaO, Ricardo (2013). Los afrodescendientes y sus organizaciones en 'Nuestra América': olvido y memoria de las banderas panafricanistas y racialistas. En Umbrales 24, pp. 107-137.
Millones, Luis (2010). Los negritos de Otuzco, en «La negrería en el Perú». Folklore. Arte, cultura y sociedad, Revista del Centro Universitario de Folklore. Universidad Nacional Mayor de San Marcos, Año 1, Número 2, Noviembre, pp. 107-126.

Molina Ludy, Virginia (1990). La historia oral y la identidad étnica. En Estudios sobre culturas contemporáneas, México, Vol. III, número 8-9, Universidad de Colima. Murra, John V. (2002). El mundo andino. Población, medio ambiente y economía. Lima: Instituto de Estudios Peruanos-Pontificia Universidad Católica del Perú, Historia Andina, 24.

"Noticia de las fuerzas enemigas en las Provincias de Jauja” (1882/1991) en Memorias del General O'Realy, Comunicado enviado por Francisco Vidal, 30 de septiembre de 1823, VII (1821-1823)-XX, pp. 1-2, Edición facsimilar publicada por el Ministerio de Defensa de la República de Venezuela, disponible en http://dspace.bolivarium.usb.ve/dspace/bitstream/ 123456789/12937/1/ol-t020p0111.pdf.

Orellana Valeriano, Simeón (1990). Folklore. Huancayo: Universidad Nacional del Centro del Perú, Facultad de Pedagogía y Humanidades, Programa de Profesionalización Docente. Texto Universitario, Quinto Año.

Orellana Valeriano, Simeón (2007). Mitos y danzas rituales del valle del Mantaro. Lima: Fondo Editorial del Pedagógico San Marcos, Serie: Arte, Cultura y Sociedad.

Pampa Chaccalla, Luis Armando (1991). Interpretación sociológica de las danzas en el valle del Mantaro. Huancayo: Universidad Nacional del Centro del Perú, monografía.

Panfichi, Aldo (2000). Africanía, barrios populares y cultura criolla a inicios del siglo xx. En María Rostworowski, Javier Mariátegui, Carlos Aguirre... [et al.]; Lo africano en la cultura criolla, presentación de Martha Hildebrandt. Lima: Fondo Editorial del Congreso del Perú.

Parra Herrera, Miryan Yovanna (2009). Poder y estudios de las danzas en el Perú. Lima: Universidad Nacional Mayor de San Marcos, Facultad de Ciencias Sociales.

Quijano, Aníbal (2007). Prólogo. José Carlos Mariátegui: reencuentro y debate. En José Carlos Mariátegui, 7 ensayos de interpretación de la realidad peruana. Caracas: Fundación Biblioteca Ayacucho-República Bolivariana de Venezuela, Colección Clásica N. ${ }^{\circ} 69$. 
Robles Mendoza, Román (2012). La memoria colectiva a través de las danzas. En Investigaciones Sociales, Vol.16 $\mathrm{N}^{\circ} 29$, pp.141-158, Universidad Nacional Mayor de San Marcos-IIHS, Lima.

Rocca Torres, Luis (2010). Herencia de esclavos en el norte del Perú (Cantares, danzas y música). Lima: Centro de Desarrollo Étnico-Embajada de Espańa en Perú, Serie Mano Negra/3.

Rodríguez Pastor, Humberto (2005). Abolición de la esclavitud en el Perú y su continuidad. En Investigaciones Sociales, Año IX No 15, pp. 441-456, Universidad Nacional Mayor de San Marcos,-IIHS, Lima.

Rojas de la Torre, Oscar y Palacios Villanes, Marco Antonio (1988). Wanka Mayu. Río de los Huancas. Danzas típicas del Valle del Mantaro. Lima: Lluvia Editories.

Romero, Raúl R. (2004). Identidades múltiples. Memoria, modernidad y cultura popular en el Valle del Mantaro. Lima: Fondo Editorial del Congreso del Perú.

Rostworowski, María (1988). Historia del Tahuantinsuyu. Lima: Instituto de Estudios Peruanos - Consejo Nacional de Ciencia y Tecnología.

Rostworowski, María (2000). Lo africano en la cultura peruana. En María Rostworowski, Javier Mariátegui, Carlos Aguirre... [et al.]; Lo africano en la cultura criolla,presentación de Martha Hildebrandt. Lima: Fondo Editorial del Congreso del Perú.

Sánchez, Carlos (2010). La Negrería en Huancaya, en "La negrería en el Perú». Folklore. Arte, cultura y sociedad, Revista del Centro Universitario de Folklore. Universidad Nacional Mayor de San Marcos, Año 1, Número 2, Noviembre, pp. 15-70.
Schmidt, Bettina E. (2007). Afro-Peruvian Representations in and around Cusco: a Discussion about the Existence or Non-existence of an Afro-Andean Culture in Peru. En Indiana 24, 2007, pp. 191-209.

Serna Moreno, J. Jesús María (2014). Propuesta teóricometodológica para el proyecto colectivo de investigación 'Afroindoamérica'. En Afroamérica. Historia, cultura e identidad. México: Centro de Investigaciones sobre América Latina y el Caribe, Universidad Nacional Autónoma de México, Colección Historia de América Latina y el Caribe.

Serna Moreno, J. Jesús María, y Ricardo Solís Herrera (coordinadores) (2012). Presentación. En Afroamérica. Historia, cultura e identidad, México: Centro de Investigaciones sobre América Latina y el Caribe, Universidad Nacional Autónoma de México, Colección Historia de América Latina y el Caribe.

Serna Moreno, J. Jesús María (2010). Cultura e identidad de los pueblos afroamericanos. En Pueblos, diásporas y voces de América Latina 1, México, coordinadores Ricardo Melgar y Rossana Cassigoli, México, Universidad Nacional Autónoma de México.

VÁsquez, Chalena (2010). El Qhapaq Negro, en «La negrería en el Perú». Folklore. Arte, cultura y sociedad, Revista del Centro Universitario de Folklore. Universidad Nacional Mayor de San Marcos, Año 1, Número 2, Noviembre, pp. 71-106.

VÁsquez, Chalena (s/f). Costa. Presencia africana en la costa peruana. Relación de géneros, danzas e instrumentos musicales. Lima.

Vilcapoma, José Carlos (2008). La danza a través del tiempo en el mundo y en los Andes (Un enfoque antropológico). Lima: Universidad Nacional Agraria La Molina. 